\title{
A Feminist Interpretation of Marlene Nourbese Philip's She Tries Her Tongue, Her Silence Softly Breaks
}

\author{
$\mathrm{Li} \mathrm{Wu}$ \\ University of Jinan \\ Shandong, China
}

\author{
Xianmei Ji \\ Wenxin Senior High School \\ Shandong, China
}

\begin{abstract}
This essay aims at a feminist interpretation of Marlene Nourbese Philip's collection of poems She Tries Her Tongue, Her Silence Softly Breaks from three dimensions, namely "i-mage" of African Caribbean women, the genealogy of women and maternal myths, to interpret Philip's feminist authorial intentions and ideological pursuits.
\end{abstract}

Keywords-Marlene Nourbese Philip; She Tries Her Tongue, Her Silence Softly Breaks; feminism; "i-mage”; genealogy; myth

\section{INTRODUCTION}

Marlene Nourbese Philip (1947- ) is an AfricanCaribbean-Canadian woman poet, essayist, novelist, playwright and short story writer, who was born and brought up in Trinidad and Tobago, now a Canadian citizen. She is best known for her collection of poetry She Tries Her Tongue, Her Silence Softly Breaks (1989, hereafter shortened as She Tries Her Tongue) which won the prestigious Casa de las Américas Prize for poetry in 1988, and made her "the first anglophone woman, and the second Canadian, to win the prize" (http://www.nourbese.com/poetry/she-tries-her-tongue/, retrieved on July 31,2018 ).

She Tries Her Tongue is widely acclaimed not only for its original language view, experimental writing style, but also for its rich cultural contents, courageous ideological intentions and thought-provoking postcolonial and feminist themes. Mark Ford observed "(Nourbese Philip) defines her language as 'Caribbean demotic', and is principally concerned with evolving a literary style that fully reflects the speech habits of both her native land and inner thought patterns. Many of the book's poems directly confront the dilemma she encapsulates in a bitter pun- 'language 1/anguish anguish-a foreign anguish'...Philip's poetry encompasses an all-inclusive verbal awareness" (1995). Jayne Cortez claimed "Philip asserts herself at the intersection where South meets North, rupturing words and concepts...in search of a new path to redirect and rearrange the logic of her literary tongue" (1989). The publisher of the Women's Press praised She Tries Her Tongue as "an extended jazz riff running along the themes of language, racism, colonialism and exile" (1993, back cover).
We, two Chinese women readers, see more value in the feminist consciousness conveyed in her new "i-mage" of African Caribbean women, the genealogy of women and maternal mythology that she creates. So, this essay aims at a feminist interpretation of Philip's She Tries Her Tongue with the hope of contributing a little to the better understanding of Philip's authorial intentions and ideological pursuits.

\section{II. “I-MAGE” OF AFRICAN CARIBBEAN WOMEN}

Virginia Woolf held that if women want to get engaged in writing, they have to kill the image of "angel in the house" -- the socially acceptable ideal of docile womanhood first created by Coventry Patmore in his "The Angel in the House" (1954), a narrative poem highly acclaimed by Carol Christ as "culturally significant, not only for its definition of the sexual ideal, but also for the clarity with which it represents the male concerns that motivate fascination with that ideal" (https://en.wikipedia.org/wiki/The_Angel_in_the_House). However, Virginia Woolf's slogan is shouted only for the white female, because the black women have never been thought as angels. In the age of slavery, they were reduced to "de mule uh de world (the mule of the world)", as Janie's grandma, a nigger woman in Zora Neale Hurston's Their Eyes Were Watching God, most sadly put it in the following quotation:

So de white man throw down de load and tell de nigger man tuh pick it up. He pick it because he have to, but he don't tote it. He hand it to his womenfolks. De nigger woman is de mule uh de world so far as Ah can see. (2013: 14)

Even today, when black women's livelihood is much improved, in most westerner writers' works their images still remain "predominately negative" as Philip put it in her essay "The Absence of Writing of How I Almost Became a Spy" in the following quotation:

...there are certain historical and sociological, not to mention etymological, reasons why when we hear certain words and phrases, such as "thick lip" or "kinky hair", the accompanying images are predominately negative. From 
whose perspective are the lips of the African thick or her hair kinky? Certainly not from the African's perspective. And there is no denying that expression such as "thick lips" and "kinky hair" connotes far more they denote. How then dose the writer describe the Caribbean descendants of West Africans so as not to connote the negativity implied in the description such as "thick lips"? $(1997,53)$

Uncomfortable with the western writers' negative imaging of the Caribbean descendants of West Africans, Philip decides "to write about kinky hair and flat noses -maybe I should be writing about the language that kinked the hair and flattened noses, made jaws prognathous" (1997, 53). So, she recreates her own image of black people, girl, woman and men, in the poem "Meditations on the Declension of Beauty by the Girl with the Flying Cheekbones" as follows:

Girl with the flying cheek-bones:

She is

I am

Woman with the behind that drives men mad

And if not in yours

Where is the woman with a nose broad

As her strength

If not in your

In whose language

Is the men with the full-moon lips

Carrying the midnight of colour

Split by the stars - a smile

Beautiful (Philip, 1993:27)

In this poem, the girl with flying cheek-bones, the woman with the behind that drives men mad, and a nose broad as her strength, the men with the full-moon lips carrying the midnight of colour split by the stars, are much more beautiful than the western writers' prejudiced and negative images of the black with "flat nose" and "kinky hair". The African Caribbean females are equally fascinating although dramatically different from the Victorian masculine ideal of "angel in the house". What makes them more admirable is that the African Caribbean females hold fast to their own faith of African Caribbean aestheticism and are consequently very confident in their own beauty.

Philip defines these beautiful African Caribbean images as new "i-mage", and explains its concept as such:

the word "image" is being used here to convey what can only be described as the irreducible essence -- the i-mage -of creative writing; it can be likened to the DNA molecules at the heart of all life. The process of giving tangible form to this i-mage may be called i-maging, or the i-magination... "I-mage" rather than "image" is, in fact, a closer approximation of the concept under discussion in this essay...to translate the i-mage into meaningful language for the audience. (Philip, 1997: 43)

Actually, Philip's new i-mages of black women are not only beautiful but also powerful and creative, even bisexual and androgynous. In the eighth section "Testimony Stoops to Mother Tongue", the heroic image Perseus is described as a black female who masters the Gorgon. Yet, according to the Greek-Roman myth, Perseus is Danae's son who killed the evil Gorgon Medusa with snakes around her head. In contrast to the Greek-Roman myth, Perseus under Philip's pen is not only transfigured into a black female, but also a very powerful woman who can tame and breed the snakes instead of killing them. The fifth part of "Testimony Stoops to Mother Tongue" creates the new i-mage of Perseus as follows:

\section{Oh, but shall I?}

I shall

tame them--

these snakes

feed them

milk

from black breasts

(stroke and caress into

lactate)

to hush

the slithered silk of tongues

$\cdots$

to breed the again and

again

in breed

-a new breed

-a race

-a warrior race

of words

-a nest-egg

that waits

to hatch the ever

in wait (Philip, 1993:54-55)

Hélène Cixous eulogized the prodigious drive of women, and believed "her libido will produce far more radical effects of political and social change than some might like to think" (1976: 882). Philip's new i-mage of Perseus who feeds the snakes with "milk/ from black breasts" also possesses the great power of fertility and productive libido 
that can breed the snakes, hatch a nest-egg, and create a new breed, a race, a warrior race. Hélène Cixous also claimed "woman is bisexual", and believed the "self-effacing, merger-type bisexuality...doesn't annual differences but stirs them up, pursue them, increases their number" (884). Virginia Woolf proposed the concept of "androgyny", which shares similar concept of bisexuality. So, Philip makes "an active revisioning of history and mythology to parallel and counter the myths of Black inferiority" (Guttman, 53), and creates such a bisexual and androgynous figure as Perseus, an idealistic unity of phallic power of creation and libido power of reproduction, of masculinity and femininity in She Tries Her Tongue.

\section{GENEALOGY OF WOMEN}

Another striking feminist feature of She Tries Her Tongue is shown in Philip's genealogy of woman composed exclusively of women where male images rarely appear throughout the whole collection.

In the first section "And Over Every Land and Sea", the i-mage of "she", sometimes a mother, sometimes a daughter, runs through all the poems. While the quoted Greek-Roman myth of Ceres and Proserpine from Ovid's Metamorphoses has two male figures, Zeus and Hades, under Philip's pen they are absent. The second section "Cyclamen Girl" centers on the cyclamen girl. In the poem "Transfiguration", the central i-mages of Aphradite, Ave Marie, Atabey, Oshun are all Christian or African goddesses. In Of Women, Wisdom, Fishes and, Men, a book invented by Philip, she weaves a story about a skeleton's returning that takes place in a mini-kingdom of women as follows:

... and on the day of the great salmon run, the first salmon caught is cooked and shared among the elders -men and women. The oldest woman of the tribe, accompanied by the youngest girl-child, then goes down to the waters and returns the skeleton whole to its watery home. This is the way the tribe ensures future gifts of winter food. (Philip, 1993: 73)

In this mini-kingdom of women, the oldest woman accompanied by the youngest girl-child goes down to the waters and returns the skeleton of the first salmon to the river so that they could ensure food for the next winter, ensure the fertility of the salmon, and guarantee the prosperity of their race.

Sandra Gilbert and Susan Gubar once observed to the effect that American minority women writers are inclined to find a female ancestor as their inspiration of creation. The oldest woman is just Philip's female ancestor. She and the girl-child symbolize a pedigree that breaks away from the patriarchy, and builds up their own genealogy of women.

The title "Of Women, Wisdom, Fishes and, Men" also reminds readers of a proverb "A woman needs a man like a fish needs a bicycle" coined by Irina Dunn and popularized by Gloria Steinem later (qtd. in Kassian,
2012). This phrase implicates that men might be of no need or even of no use to women. Then, how can Philip's women-only society and her exclusively female lineage continue its genealogical succession? "Epiphany" collected in the second section "Cyclamen Girl" answers the question through a myth as follows:

In a land of shadows

Herring-boned with memory,

The great stone-bird mother

Sweet-balmed with honey

Drops her daughters

From her open beak

-Like pebbles

Pebbled of blood and stone;

The cyclamen girl returns

To her own (Philip, 1993: 19)

Epiphany is a Christian festival held on the 6 January in memory of the time when the MAGI came to see the baby Jesus at Bethlehem. In this poem, the cyclamen girl is dropped into life by a "stone-bird" mother, like "pebbles of blood and stone". This myth presents a genealogical succession from mother to daughter, where a father or a male is no longer a must to the process of reproduction.

\section{MATERNAL MYTHOLOGY}

Hélène Cixous said in her "The Laugh of the Medusa" that "In women there is always more or less the mother who makes everything all right, who nourishes, and who stands up against separation; a force that will not be cut off but will knock the wind out of the codes" (1976:882).

Alice Walker stressed in her The Temple of $M y$ Familiar (1989) the irreplaceable role of her mother who had furnished her with spiritual strength and precious inspiration. What Walker eventually discovered is not only her mother's temple but that of her own.

In Philip's poems, mother is also the source of creation, holding the key to a new world where there is no male domination. The magnificent genealogy of woman that Philip weaves is also centered on the mother, whose force is great enough to establish the maternal mythology. The myth of the great stone-bird mother in "Epiphany" is one of her maternal myths. Another maternal myth is created in the following two excerpts from the poem "Discourse on the Logic of Language".

WHEN IT WAS BORN, THE MOTHER HELD HER NEWBORN CHILD CLOSE; SHE BEGAN THEN TO LICK IT ALL OVER. THE CHILD WHISPERED A LITTLE, BUT AS THE MOTHER'S TONGUE 
MOVED FASTER AND STRONGER OVER ITS BODY, IT GREW SILENT-THE MOTHER TURNING IT THIS WAY AND THAT UNDER HER TONGUE, UNTIL SHE HAD TONGUED IT CLEAN OF THE CREAMY WHITE SUBSTANCE COVERING ITS BODY. (Philip, 1993:30)

THE MOTHER THEN PUT HER FINGERS INTO HER CHILD'S MOUTH-GENTLY FORCING IT OPEN; SHE TOUCHES HER TONGUE TO THE CHILD'S TONGUE, AND HOLDING THE TINY MOUTH OPEN, SHE BLOWS INTO IT-HARD. SHE WAS BLOWING WORDS-HER WORDS, HER MOTHER'S WORDS, THOSE OF HER MOTHER'S MOTHER, AND ALL THEIR MOTHERS BEFORE-INTO HER DAUGHTER'S MOUTH. (Philip, 1993: 32)

These two excerpts accentuate Philip's definition of "mother-tongue", i.e. "her words, her mother's words, those of their mother's mother and all their mothers before". When the mother, the poem's central image, touches her tongue to the child's tongue and blows words into her daughter's mouth, the process of mother-tongue inheritance is completed. And this process will continue to later generations. Every language carries the culture and memory and history of its nation and race. Therefore, the mother-daughter pattern linguistic inheritance becomes the cornerstone of the Afro-Caribbean cultural legacy. The unusual capitalization of the above quotations also exalts the divinity of cultural inheritance through maternal lineage, where the mother and daughter go back to a "Pre-Oedipus phase" (qtd. in Zhang, 118) when women's rights have not been diminished nor deprived by men, and the image of mothers has not been distorted by patriarchy. Although these two excerpts are listed lengthwise on the far left margin of the page, they beautifully illustrate the chronological succession of time and cultural inheritance from generation to generation, and become the most eye-catching and impressive piece among the four registers of the poem "Discourse on the Logic of Language". The dedication page of She Tries Her Tongue reads "For all the mothers". So, we have very good reasons to interpret the whole collection as a sacred hymn to all the mothers and to the myths they create with their maternal love, courage, creativity and perseverance.

\section{CONClusion}

As a "developer of literary frontiers that serve the culturally complex horizons of newly constituted societies" (Savory, 297), Marlene Nourbese Philip makes great effort to create new i-mages of the beautiful and confident African Caribbean women, who have been silenced and marginalized, and whose images have been distorted by the white writing for too long a time. Philip also establishes in her poetic world a women-only society and creates her genealogy of women where the male are absent or silenced through "cultural patricide" (Wu, 2017:162), while the female triumphantly expand their "existential boundaries" (Philip, 1980: 25) and display their bisexuality and androgyny. At the same time, Philip creates her maternal mythology where all the mothers are deified to be the exclusive inheritor of the African Caribbean national culture, memory, history as well as mother-tongue. So, it is very natural for the publisher of The Women's Press to recommend She Tires Her Tongue as such: "In this outstanding and groundbreaking collection Philip defiantly challenges and resoundingly overthrows the silencing of black women through appropriation of language, offering no less than superb poetry resonant with beauty and strength"(1993, back cover).

\section{REFERENCES}

[1] Cixous, Hélène. The Laugh of the Medusa [J]. Trans. Keith Cohen and Paula Cohen, Signs, 1976, (Summer): 875-893.

[2] Cortez, Jayne. Review of She Tries Her Tongue; Her Silence Softly Breaks [N]. Books in Canada, 1989-1-18.

[3] Ford, Mark. Review of She Tries Her Tongue; Her Silence Softly Breaks [N]. The Guardian, 1995-6-16.

[4] Guttman, Naomi. Dream of the mother language: myth and history in She Tries Her Tongue, Her Silence Softly Breaks [J]. MELUS, 1996, (2): 53-68.

[5] Hurston, Zora Neale. Their Eyes Were Watching God [M]. New York: Harper Perennial Modern Classics, 2013.

[6] Kassian, Mary. Women aren't fish and men aren't bicycles [N]. Girls Gone Wise, 2012-4-1.

[7] Philip, Marlene Nourbese. Thorns[M]. Toronto: Williams-Wallace International Inc., 1980.

[8] Philip, Marlene Nourbese. She Tries Her Tongue; Her Silence Softly Breaks [M]. London: The Women's Press Ltd., 1993.

[9] Philip, Marlene Nourbese. A Genealogy of Resistance and Other Essays[M]. Toronto: The Mercury Press, 1997.

[10] Savory, Elaine. Marlene Nourbese Philip [A]. Dictionary of Literary Biography, Volume 157: Twentieth-Century Caribbean and Black African Writers, Third Series[Z]. Eds. Bernth Lindorfs and Reinhard Sander. Detroit: Gale Research Inc., 1996: 296-306.

[11] Zhang, Yanbing. Feminist Theories[M]. Jinan: Shandong Education Press, 1998.

[12] Wu, Li. A Postcolonial-feminist Interpretation of Marlene Nourbese Philip's Poetry. Jinan: Shandong University Press, 2017. 